UDC 338.2:351.777.61:005.932 JEL: R49, Q58

\section{Milena Tepavicharova}

Professor,

Higher School of Security and

Economics,

Plovdiv, Bulgaria

E-mail: m_ivanova_zlatanova@abv.bg orcid.org/0000-0003-3759-5426

\section{Lyudmila Dikova}

Associate Professor,

Higher School of Security and

Economics,

Plovdiv, Bulgaria

E-mail: 1_boykova@abv.bg

orcid.org/0000-0001-6861-0727

Received: July, 2019

Accepted: August, 2019

DOI: 10.31520/2616-7107/2019.3.3-3

(C) Economics. Ecology. Socium, 2019

CC BY-NC 4.0 license

\section{SOCIAL MEDIA - ON THE EDGE BETWEEN PERSONAL AND PROFESSIONAL DEVELOPMENT}

Introduction. Social media steadily and constantly envelops all aspects of peoples' lives. Thus it is of crucial importance to investigate and measure social media activities' impact on their inclusion in the formation of today's and future societies as more and more online activities have been incorporated in real life personal and professional activities.

Aim and tasks. This article explores the new trends in people's activities at the workplace and outlines the main concerns regarding keeping the line between personal and professional online activities.

Results. Social media are now an integral part of the everyday life of modern man. Since a person spends most of their day at work or in pursuit of their profession, they also seek to engage in personal activities within the working day (talking on the phone with family or friends, shopping online, reading news etc.).

A user is created with features specific to the internet generation. This new type of user has specific features that allow researchers to talk about the emergence of a nextgeneration user. The Next Generation User is a person who has access to the Internet from multiple locations and devices.

The rapid penetration of social media in people's everyday life implies a greater impact on all users' real-life and online activities. Evidence of the latter can be found in very common situations when users upload photos or videos from parties or events in real time not always tacking into consideration the possible outcomes for their personal and professional lives.

Conclusions. Managers consider that workers should focus more not only on the technical limitation of the exchange in of information on social media but also on a better personal judgment about the nature and volume of the shared information. The intensity of social media activities of the workers is monitored actively by employers and coworkers alike and can be seen as an indicator of low efficiency or irresponsible personality. With the fast development of wireless mobile telecommunications technology and the growing multitude of mobile apps online activities become a real threat for workers' productivity and the development of workplace culture.

Keywords: social media, Information and communication technologies, next-generation user, workplace culture. 


\section{UDC 338.2:351.777.61:005.932 JEL: R49, Q58}

\section{Мілена Тепавичарова}

Професор,

Вища школа безпеки та економіки, Пловдив, Болгарія

E-mail: m_ivanova_zlatanova@abv.bg orcid.org/0000-0003-3759-5426

\section{Людмила Дікова}

Доцент,

Вища школа безпеки та економіки, Пловдив, Болгарія

E-mail: 1_boykova@abv.bg orcid.org/0000-0001-6861-0727

Отримано: Липень, 2019

Прийнято: Серпень, 2019

DOI: 10.31520/2616-7107/2019.3.3-3

(C) Економіка. Екологія. Соціум, 2019 CC BY-NC 4.0 ліщензія

\section{СОЦІАЛЬНІ МЕДІА - НА МЕЖІ МІЖ ОСОБИСТИМ І ПРОФЕСІЙНИМ РОЗВИТКОМ}

Вступ. Соціальні медіа незмінно i постійно охоплюють всі сторони життя людей. Таким чином, вкрай важливо дослідити і виміряти вплив діяльності соціальних мереж на їхнє включення в формування сьогоднішніх $\mathrm{i}$ майбутніх суспільств, оскільки все більше і більше онлайндій включається в реальну особисту і професійну діяльність.

Мета і завдання. У цій статті розглядаються нові тенденції в діяльності людей на робочому місці i викладаються основні проблеми, що стосуються дотримання межі між особистою та професійною онлайндіяльністю.

Результати. Соціальні мережі тепер є невід'ємною частиною повсякденного життя сучасної людини. Оскільки людина проводить більшу частину свого дня на роботі або в пошуках своєї професії, він також прагне займатися особистою діяльністю протягом робочого дня (розмовляти по телефону 3 сім'єю або друзями, робити покупки в Інтернеті, читати новини і т.п.). Користувач створено 3 функціями, характерними для покоління в Інтернеті. Цей новий тип користувачів має специфічні особливості, які дозволяють дослідникам говорити про появу користувача наступного покоління. Користувач наступного покоління це людина, яка має доступ до Інтернету з різних місць і 3 різних пристроїв. Швидке проникнення соціальних мереж в повсякденне життя людей тягне за собою великий вплив на реальну і онлайн-активність всіх користувачів. Свідоцтво останнього можна знайти в дуже поширених ситуаціях, коли користувачі завантажують фотографії або відео 3 вечірок або подій в режимі реального часу, не завжди беручи до уваги можливі результати свого особистого та професійного життя.

Висновки. Менеджери вважають, що працівникам слід приділяти більше уваги не тільки технічному обмеженню обміну інформацією в соціальних мережах, але i покращенню особистого судження про характер і обсяги переданої інформації. Активність соціальних працівників в соціальних мережах активно відстежується як роботодавцями, так і колегами, і може розглядатися як показник низької ефективності або безвідповідальністю особистості. У зв'язку 3 швидким розвитком технологій бездротового мобільного зв'язку і зростаючою безліччю мобільних додатків он-лайнові дії стають реальною загрозою для продуктивності працівників $\mathrm{i}$ розвитку культури робочого місця.

Ключові слова: соціальні мережі, інформаційнокомунікаційні технології, користувач нового покоління, культура робочого місця. 
Introduction. Social media steadily and constantly envelops all aspects of peoples' lives. Thus it is of crucial importance to investigate and measure social media activities' impact on their inclusion in the formation of today's and future societies as more and more online activities have been incorporated in real life personal and professional activities. "The diversity offered by electronic communication poses new challenges to traditional values and behavioral models" (Boykova, 2016) [1].

In the recent decades modern ICT (Information and communication technologies) made connecting people easier than ever. "Various channels for multi-directional dissemination of information already exist on the Internet" (Boykova, 2016) [1]. Social media profiles allow users to present themselves and communicate with each other in the cyberspace with practically no additional technical or software skills. Sites like Facebook provide people with multiple opportunities for selfexpression and communication through their online profiles. Social media increasingly becomes an integral part of the everyday life of millions of people - particularly of young people all over the world.

The multifaceted nature of social media tool for self-presentation of identity (Subrahmanyam \& Šmahel, 2011) [2] in both the online and offline world, a medium for communication (Pempek et al., 2009; QuanHaase \& Young, 2010) [3, 4] an area for leisure activities (Stewart, 2016; Janković, 2016) [5, 6], political debates (Thorson, 2014) [7] explains their popular use in everyday life. With the incorporation of SNS within the user's everyday routines new patterns of SNS usage immerged. There is a current shift from the social networking understood as a pass-time to the embedding work related and education related activities in the online networking routine.

Analysis recent research and publications. In this context of emerging online challenges for the balance between online and real life activities many managers observe new trends in the patterns of behavior of the workforce especially among young workers. A lot of businesses are looking for innovative ways to improve efficiency and maintain competitive advantage in order to survive [8-10]. This requires the development of various techniques for improving their business competitiveness [11-13] and finding new ways for developing human potential [14-19].

Aim and tasks. In this article we examine what are the new trends in people's activities at the workplace. We outline the main concerns regarding keeping the line between personal and professional online activities.

Social media changed the notion of media communication which, until their appearance, "flows" mostly unidirectionally - from the media (the source of information) to the user of information, and the social and professional roles are clearly defined - the media as a news creator and the audience as a perceiver of news. Removing the boundaries between these roles in social media is one of the important changes in public communications.

Results. Anyone already having an account in the relevant social media can now be the creator of the news; to influence public opinion with the comments it publishes; to feel like a "media star", counting his "likes" and "followers"; and not, last, to organize public opinion and to induce groups of people united by a common cause to action. Social media communication is also reflected in the work process as much of the activity is recorded within the workday when employees find reasonable pretexts to justify themselves and others, the time they spend in virtual communication instead of to perform their direct duties.

Social media are now an integral part of the everyday life of modern man. Since a person spends most of their day at work or in pursuit of their profession, they also seek to engage in personal activities within the working day (talking on the phone with family or friends, shopping online, reading news etc.). The US Labor Bureau survey (2016) [20] shows what workers use their time in the days they work (Fig. 1). The most time is spent at work (8.8 hours), sleep is second ( 7.8 hours), and the rest of the activities are separated between one and two hours each (Bureau of Labor Statistics, 2016). Part of the activities that distract employees during working hours take place in the virtual space (internet, social media, chat, etc.). 
A survey of 1989 UK-based officers over 18 years of age, as part of a study of online habits and worker productivity across the country, reveals the main sources of workday scattering (Harrow, 2017) [21]. Harrows survey is outlined below and during it all respondents work full-time in an office.

Interesting is the answer to the question: "If you have to specify a figure, how long do you think you spend productively during working hours on a daily basis?". It is determined by various non-specific work activities that actual workplace productivity is on average 2 hours and 53 minutes a day. This is less than half of the working time. In order to find out how and how it distracts employees, the question has been asked: "What do you do instead of working productively?" As the main reasons for the loss of working time, respondents' answers outline 10 types of activities that divert employees from their direct duties. Respondents are allowed to choose more than one option when listing the reasons for decreasing workflow performance.

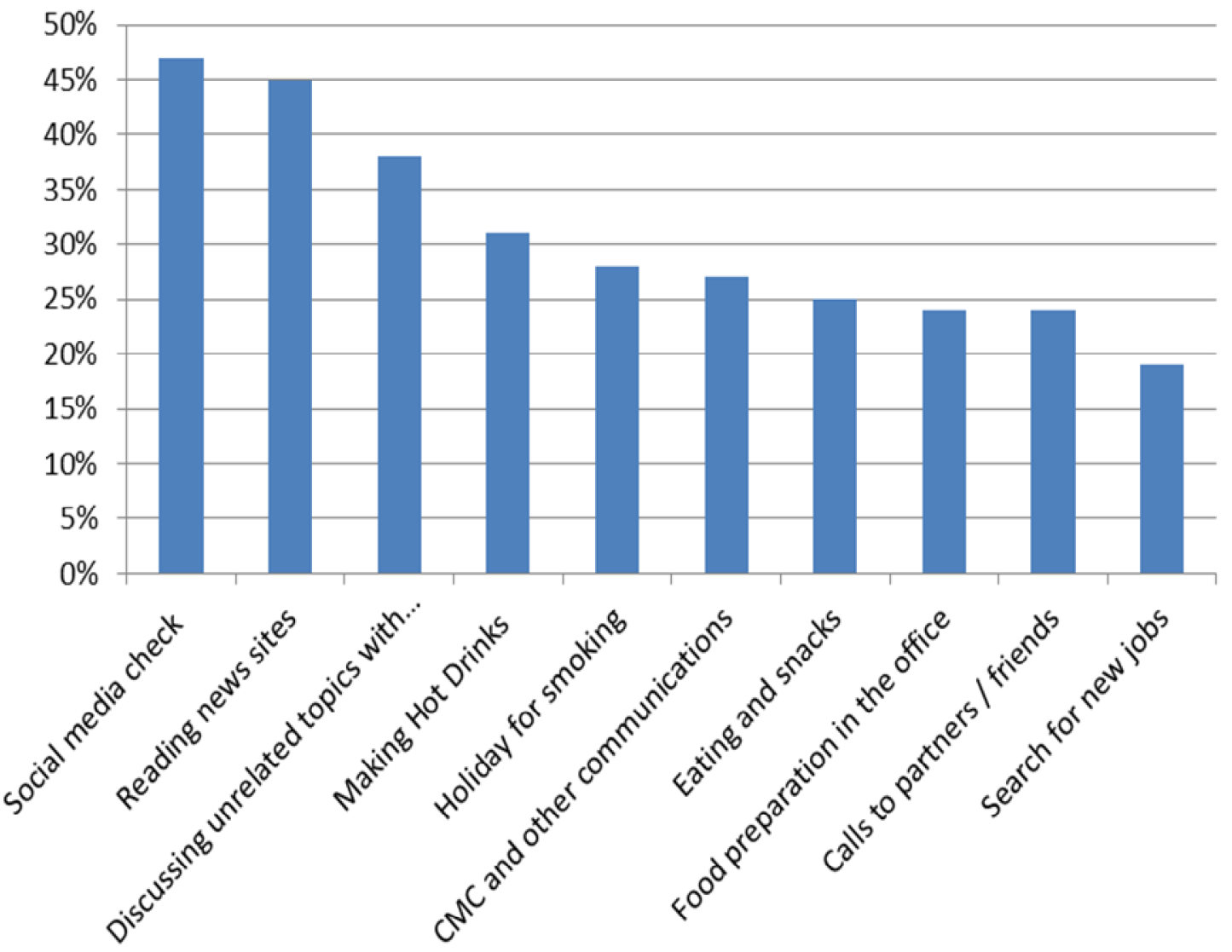

Fig. 1. Activities workers spend their time in the days they work Source: Developed by authors on Harrow (2017) [15].

The next question tells you how much time employees spend on each of the activities listed above during the day from 40 minutest to 1 hour [24]: 1. Social media check; 2. Read news websites; 3 . Discussing unrelated themes with colleagues.

According to Harrow it turns out that screening social media and reading news websites are not only the most common dissimilar activities but also take most of the employees' hours of work.

The times we uncovered in the survey, however, have surprised us - we may be able to distract too easily, as a result, our productivity is diminishing. Productivity depends on the communication competencies of each person and increasing their productivity can affect everyone [25]. 
Taking a break from time to time is good - in fact, many high-ranking business leaders recommend regular breaks to make you more productive. But listening to your friend or partner and checking social media can be too ..." [21]. ICT development allows users to interact in cyberspace virtually at any time in any location. As F. Boikova emphasizes, the electronic world is abolishing the administration of information, and the personality is primarily a form of information orientation, self-preservation, and adequate social behavior [1]. A user is created with features specific to the internet generation. This new type of user has specific features that allow researchers to talk about the emergence of a next-generation user. The Next Generation User is a person who has access to the Internet from multiple locations and devices. In particular, as a person who uses at least two internet applications (of four searched applications) on his mobile phone or who meets two or more of the following criteria: own a tablet, reader, three or more computers" [22].
Conclusion. The rapid penetration of social media in people's everyday life implies a greater impact on all users' real-life and online activities. Evidence of the latter can be found in very common situations when users upload photos or videos from parties or events in real time not always tacking into consideration the possible outcomes for their personal and professional lives. Managers consider that workers should focus more not only on the technical limitation of the exchange in of information on social media but also on a better personal judgment about the nature and volume of the shared information. The intensity of social media activities of the workers is monitored actively by employers and coworkers alike and can be seen as an indicator of low efficiency or irresponsible personality. With the fast development of wireless mobile telecommunications technology and the growing multitude of mobile apps online activities become a real threat for workers' productivity and the development of workplace culture.

\section{REFERENCES}

1. Boykova, F., (2016). Communication strategies in Bulgarian language training. PU Paisii Hilendarski, Plovdiv.

2. Subrahmanyam, K., Šmahel, D. (2011). Constructing Identity Online: Identity Exploration and Self-Presentation. Digital Youth Advancing Responsible Adolescent Development, 59-80.

3. Pempek, T. A., Yermolayeva, Y. A., \& Calvert, S. L. (2009). College students' social networking experiences on Facebook. Journal of Applied Developmental Psychology, 30(3), 227238.

4. Quan-Haase, A. \& Young, A. L. (2010). Uses and gratifications of social media: A comparison of Facebook and Instant Messaging. Bulletin of Science, Technology and Society, 30(5), $350-361$.

5. Stewart, J. (2016). Facebook Has 50 Minutes of Your Time Each Day. It Wants More. New York Times. Retrieved from http://www.nytimes.com/2016/05/06/business/.

6. Janković, B., Vukonjanski, J., Nikolić, M., \& Terek, Ed. (2016). he impact of Facebook and smart phone usage on the leisure activities and college adjustment of students in Serbia. Computers in Human Behavior, 55, 354-363. DOI: 10.1016/j.chb.2015.09.022.

7. Thorson, Kj. (2014). Facing an uncertain reception: Young citizens and political interaction on Facebook. Information, Communication \& Society, 17.2, 203-216.

8. Odinokova, T. (2019). Tourism cluster as a form of innovation activity. Economics. Ecology. Socium, 3, 1-11.

9. Koval, V., Pukała, R. (2017). Implementation of Regulatory Policy in Economic Activity: Development of the Institute Regulatory Impact Assessment. Economics. Ecology. Socium, 1, 2432. 
10. Petrova, M., Tepavicharova, M., \& Boykova, L. (2017). Improvement of the efficiency and competitiveness through the implementation of benchmarking in the organizations, KazUMO, Almaty, Kazahstan, Bulletin of Ablai Khan KazUIRandWL series INTERNATIONAL RELATIONS and REGIONAL STUDIES, 1 (27), 5-6, 79-85.

11. Petrova, M. (2012). Methods for management and analysis of the information risk. University of Veliko Turnovo and State University of Library Studies and information technologies [SULSIT] - Sofia. Vol.14, 1, 39-45.

12. Sushchenko, O., \& Petrova M. (2017). Internet Marketing as a Tool of Tourism Enterprise Strategic Management. Modern problems of enterprise management: theory and practice: Proceedings of the International Scientific and Practical Conference, 302-305.

13. Petrova, M., \& Aleksandrov, M. (2018). Automating the virtual hosts maintenance in a multi-site environment. International Congress on Business and Marketing (ICBM'18), 392-404.

14. Uteubayev, T., \& Petrova M. (2017). The development of human potential in kazakhstan's innovation economy. Business Management, 4, 75-89.

15. Franchuk, O., Petrova, M., \& Tolkachova, G. (2018). Elements of Control of Competitiveness of Telecommunication Companies. Economics. Ecology. Socium, 2, 22-30.

16. Lukjanova, J. (2019). Problems and Trends of Regional Tourism Development in Latvia. Economics. Ecology. Socium, 3, 1-11.

17. Popova, L. (2016). Media environment and its impact on young people. Education, 25 (4), 61-71.

18. Jarmusevica, V., Ilisko, D., Badjanova, J., Jukss, V., \& Petrova, M. (2019). SMART governance of integrating the strategy of corporate societal responsibility for a sustainable regional development: the case study. 19th International Multidisciplinary Scientific GeoConference SGEM, $5,645-652$.

19. Jarmusevica, V., Ilisko, D., Badjanova, J., Jukss, V., \& Petrova, M. (2019). Educating citizens for implementing the strategy of corporate social responsibility for sustainable regional development: the case study. Proceedings of EDULEARN19, 10449-10454.

20. United States Bureau of Labor Statistics (2016). Publications. Monthly Labor Review. Retrieved from https://www.bls.gov/opub/mlr/2016/.

21. Harrow, B. (2017). Survey reveals employee productivity averages 2 hours and 53 minutes a day. Retrieved from https://www.vouchercloud.com/blog/office-worker-productivity/.

22. Dutton, W.H., \& Blank, G. (2011). Next Generation Users: The Internet in Britain. Oxford Internet Survey. Oxford Internet Institute, University of Oxford.

23. Popova L. (2013). Some of the Aspects of the Diagnostical Activity of a Class-Teacher. Pedagogy, 85 (9), 1413-1420.

24. INC (2016.). In an 8-Hour Day, the Average Worker Is Productive for This Many Hours. Retrived from https://www.inc.com/

25. Koval, V., Polyezhayev, Y., \& Bezkhlibna, A. (2019). Communicative competences in enhancing of regional competitiveness in the labour market. Baltic Journal of Economic Studies, 4(5), 105-113. doi:10.30525/2256-0742/2018-4-5-105-113 